\title{
The Factors Affecting Consumers Pay with Go-Pay on Go-Jek
}

\author{
Bagudek Tumanggor ${ }^{1}$, Vitryani Tarigan ${ }^{2}$ \\ ${ }^{1}$ Lecturer in Economic Development Study Program, Universitas Simalungun, Indonesia \\ ${ }^{2}$ Lecturer in Accounting Study Program, Universitas Simalungun, Indonesia \\ bagudektumanggor67@gmail.com ${ }^{1}$,vitry-tarigan@yahoo.com ${ }^{2}$
}

\begin{abstract}
This study aims to examine and find out more clearly how the factors that influence consumers pay with Go-pay on Go-jek. As for the problem that the author raised, namely: How does the influence of easy payment of the use of GO-PAY to the interests of GO-JEK customers?This study uses a quantitative method that involves 50 respondents. Data collection is done by using questionnaires. The data obtained were analyzed using a statistical formula, i.e. using multiple regression analysis whose processing was carried out with the SPSS Version 23 program.Quantitative analysis results show that the variable ease of payment and price cuts significantly influence the use of Go-pay. Based on the results of the study, the hypothesis was accepted stating that there was a significant influence between the ease of payment and price cuts on the use of Go-pay on consumers at the Faculty of Economics, Universitas Simalungun, Pematangsiantar.
\end{abstract}

Keywords

easy payment; price-cutting, GoPay usage

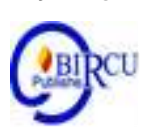

\section{Introduction}

As the times evolve, information and communication technology makes all human activities easier both in the economic and social fields. In current technological developments new innovations are needed so that all human activities become more efficient, safe, fast and comfortable, especially in the world economy. The National Digital Research Center (NDRC) states that financial technology is a new innovation combined between financial services and modern technology. The financial technology (fintech) industry is one of the methods of financial services that is gaining in popularity in the current digital era. The technology-based payment system is one of the sectors in the most developed FinTech industry in Indonesia. This sector is then most expected by the government and the community to encourage an increase in the number of people who have access to financial services.

PT. GO-JEK Indonesia is a mobile application provider company that provides a complete range of services ranging from transportation, logistics, payment services, and other services (www.gojekindonesia.com). Go - Jek develops a variety of innovations in its services as a solution and convenience in dealing with the problems of today's society. Services offered in the Go-Jek application include Go-Ride, Go-Car, Go-Food, Go-Credit, Go-Send, Go-Point, Go-Bills, Go-Box, Go-Shop, Go-Mart, Go-Tix, Go-Med, and Go-Pay. Go-Pay is an electronic wallet service to facilitate online payment transactions on the Go-Jek application. In other words, Go - Jek is a company that supports financial technology by being one of the parties involved in organizing mobile payment transaction processing.

System usage (actual system usage) is a real condition of the use of a technology system that can be measured based on the intensity of use and duration of use. So if the user uses the Go-Pay service intensively, it can be said that the user knows the Go-Pay payment 
system well. The level of Go-Pay acceptance by its users can be seen from several factors. The factors that influence the use of the Go-Pay payment system are easyf payment and price cuts. These factors are tested based on the Technology Acceptance Model (TAM) construction model.

Perceived easy payment is one of the basic determinants of technology acceptance. Thus, a user will use a payment system if it is easy to use the system. So users hope that while using Go-Pay can reduce their effort, time and energy while using it.

Research on technology acceptance has been extensively studied but acceptance of GoPay payment services is still relatively small. The study will use respondents of Go-Pay service users, namely customers who are users who make Go-Pay payments. The variable used in the use of Go-Pay is the dependent variable. In this study using a questionnaire made according to each variable in this study.

\section{Review of Literature}

\subsection{Theoretical Basis}

\section{a. TAM (Technology Acceptance Model)}

Technology Acceptance Model (TAM) is a model developed to analyze and understand the factors that influence the acceptance of the use of a technology. Based on the above definition, TAM is used to explain the acceptance or rejection of technology. The TAM model shows a number of factors that influence users' decisions about how and when they use a new technology. But in the TAM model, easy payment is a determining factor in the acceptance of technology use. This study does not fully explain the TAM model. This study only takes convenience in payment as a factor that influences the use of the Go-Pay payment system.

This variable is a basic factor that users pay attention to when they first decide to use a technology. easy payment to accept Go Pay usage. This research includes other factors that may influence the acceptance of use Go-Pay service, namely payment convenience and price cutting.

\section{b. Mobile Payment}

Mobile payment system is a form of payment made with mobile devices, such as smartphones and tablets.

\section{c. Go-Pay}

Go-Pay is a form of FinTech innovation. Other services available in the Go-Jek application are Go-Ride, Go-Car, Go-Food, Go-Credit, Go-Send, Go-Point, Go-Bills, GoBox, Go-Mart, Go-Tix, and Go-Med. Go-Ride and Go-Car are online transportation services. Go-food is a food delivery service. Go-Mart is an instant shopping service. Go-Send is an instant courier service. Go-Box is a service for ordering pick-up cars, repair trucks and box repair trucks for various purposes such as moving or sending goods with large capacity. GoTix is a ticket service for entertainment shows and movie watching. Go-Med is a service of buying and redeeming drugs. Go-Bills is a service for paying various bills such as electricity bills using the Go-Pay balance. Then there is the Go - Point which is the point obtained when using a Go-Pay balance that can be exchanged for a variety of attractive prizes. The Go-Pulsa service is a service to buy credit balances (www.gojekindonesia.com). Go-Jek users can choose 2 ways of payment for all services available on the Go-Jek application, using cash and Go-Pay. 


\section{d. System Usage}

The use of the system (actual system usage) is the condition of the use of an information technology system which is a form of measurement of how often and how long the use of technology. Thus, actual usage is measured based on the amount of time spent interacting with a technology and the frequency of its use. The use of a system that is easy to use and can increase one's productivity raises satisfaction in using the system which is reflected in real conditions.

\subsection{Marketing}

\section{a. Understanding Marketing}

Marketing activities are the beginning of a company's activities in maintaining the survival of the company to grow and make a profit. Kotler (2008: 6), defines marketing is a social and managerial process in which individuals or organizations get what they need and want through the creation and exchange of values with the others. The American Marketing Association in his book Kotler and Keller (2008: 6), explains marketing is an organizational function and a set of processes for creating, communicating, and delivering value to customers and managing customer relationships by benefiting organizations and their shareholders .

Based on the explanation above, it can be concluded that marketing is a business activity including the work of the seller looking for a buyer, recognizing the needs of consumers, planning the products to be marketed appropriately, determining a reasonable selling price, promoting the product, and distributing it.

\section{b. Online Marketing}

Online Marketing Nowadays, the means to communicate and sell products or services directly to consumers can be done quickly through electronic media. The internet provides opportunities for marketers and consumers to interact more closely. Marketing through internet media allows a business to provide services to customers without the need HR, reducing facilities and services via telephone. Online marketing can be a part of direct marketing and interactive marketing. Through online marketing, individual business institutions or companies can market products produced through the internet and can known by the wider community of internet users

Online marketing is marketing done through an interactive online computer system that connects consumers and sellers electronically. Online marketing better known as e-commerce is a term that describes the sale of goods and services via the internet. In Indonesia, internet user penetration reaches 45 million users active. Markplus Insight's research shows, from people who have bought online, transactions are carried out on sites, blogs, kaskus, and facebook. The types of items purchased online are clothes and computers. The way they prefer payment is transfer payment via ATM or COD (Cash on Delivery) and security is one of the reasons. Online Consumers When marketers market products and services via the internet, then the target market is consumers who have access to the internet. While in relation to demographic characteristics, consumers who buy goods online are on average young and have high education and income.

\subsection{Consumers}

\section{a. Understanding Consumers}

According to Dewi (2013: 1), the definition of a consumer is someone who uses a product (goods and / or services) that is marketed. According to Sri Handayani (2012: 2), the 
understanding of consumers is a person / organization that buys or uses a number of goods or services from other parties. According to Philip Kotler (2000) in his book "Principles Of Marketing", the understanding of consumers is all individuals and households who buy or obtain goods or services for personal consumption. Based on the above explanation it can be concluded that consumers are all individuals and households that buy or use a number of goods and services for personal consumption.

\section{b. Online Consumers}

Online Consumers When marketers market products and services via the internet, then the target market is consumers who have access to the internet. Whereas in relation to demographic characteristics, consumers who buy goods online average - In Indonesia, the results of a survey conducted by APJII (Indonesian Internet Service Providers Association) in 2016 showed that the most users by age were aged 35-44 years by $29.2 \%$. Whereas based on the content that is most frequently visited, internet users most often visit the online website by 82.2 million or $62 \%$. The survey results show that the number of online consumers in Indonesia is quite large, amounting to $62 \%$ of the total average internet user who is young and has high education and income.

\section{c. Consume Satisfaction}

1) Definition of Consumer Satisfaction

Kotler (2008) indicates that customer satisfaction is a very satisfied customer who generally lasts longer, buy more when the company introduces new products and increases existing production, talk about pleasant things about the company and its products. If the performance exceeds expectations they will feel satisfied and vice versa if the performance does not meet expectations it will be disappointed. An impulse of individual desires directed at the goal of gaining satisfaction. In this case we need to know that a desire must be created or encouraged before fulfilling a motive. Sources that encourage the creation of a desire can be different from oneself or are in their environment.

From some of the definitions above it can be concluded that customer satisfaction is the feeling of a customer after receiving the performance results he thinks about the expected performance of the comparison results. Loyal consumers can be encouraged by receiving service from a positive employee attitude. The concept of customer satisfaction is not new, but its emergence as a new operational concept began in the mid-1970s. Precisely in 1977 when the conference report on conceptualization and measurement of customer satisfaction / dissatisfaction was first published. The word satisfaction (statisfaction) itself comes from the Latin "static" (meaning pretty good, adequate) and "facto" (to do or make). Satisfaction can be interpreted as "efforts to fulfill something" or "make something adequate".

2) Measurement of Consumer Satisfaction

According to Philip Kotler 2008: 179 there are several methods in measuring customer satisfaction summarized as follows:

- Complaints and Suggestions Systems Every customer-oriented organization needs to provide extensive opportunities for its customers to submit their suggestions, opinions and complaints.

- Ghost Shooping By hiring several people to act or act as potential customers of the company's products and competitors, then they will report the weaknesses of the competitors' company's products. 
- Customer Satisfaction Survey Conduct interviews with customers who quit after stopping buying and monitor the level of customer loss.

- Factors that influence consumers buying online

- Factors that influence consumers to buy online consumers shop online because it is faster and easier to compare products and services. Consumers can order products whenever they need for twenty-four hours and do not need to walk far just to buy and try the product. According to Devaraj et al.: 00003 online purchasing decisions are influenced by: Efficiency for searching (fast time, easy to use, and easy search effort), Value (competitive price and good quality), and Interaction (information, security, load time, and navigation).

Ahuja et al.: 00003 in his research shows that the reasons that motivate consumers who are students to buy products or services online are convenience (28\%), saving time (23\%), better prices (25\%), availability of products / services ( $19 \%)$, service to customers (3\%) and other reasons $(3 \%)$. While the reasons for consumers with non-student status are the same as consumers with student status, only in different order. Ajja et al. : 2003 in his research found that the factors that prevent consumers of student status in shopping online are security / privacy (28\%), service to customers (22\%), lack of interaction between sellers and consumers $(15 \%)$, high prices $(13 \%)$, lack of time $(11 \%)$, can not try the product to be purchased $(4 \%)$, and other reasons $(6 \%)$. While the reasons for consumers with non-student status are the same as consumers with student status, only in different order.

Factors that influence online purchases can be grouped into internal factors, namely consumer psychology, and external factors. External factors consist of marketing stimuli, the socio-cultural environment of the community, and control systems from vendors. While research shows that online purchasing decisions are influenced by internet infrastructure and internet security. Forms of competitive advantage include comfort, speed, trustworthiness, practicality, security, and tariffs.

Research on Gojek consumers has been carried out by several researchers in Indonesia. Conducting research on 50 Gojek service users in Pematangsiantar. The results show that there are six initial factors that become consumers' preferences in using Gojek services in Pematangsiantar, including: practicality, tariffs, speed, security, trust, comfort. The results also showed that in this study a new factor was formed called the competitive advantage factor of Gojek and the most dominant factor that became the preference of consumers in using Gojek services was comfort factor.

\subsection{Hypothesis Formulation}

a. Perception of easy payment (H1)

Perception of Ease Kamus Besar Bahasa Indonesia, perception is the process of a person knowing several things through his five senses, while convenience is something that can facilitate and facilitate business, so that perception of ease can be interpreted as a person's process of knowing something that can simplify and facilitate his business through his five senses. In research conducted by defining perceptions of ease as a term that represents the extent to which an innovation is considered not difficult to understand, and to operate, and the extent to which consumers feel a new product or service is better than the product or service it replaces. The extent to which innovation can be understood and used is as a perception of ease of use.

In TAM, the perception factor of the ease of using technology and the perception of the effectiveness of an information technology are related to one's attitude towards the use of the technology. The attitude of using something is the attitude of like or dislike towards the use 
of a product or service. Like or dislike attitude towards a product or service can be used to predict someone's behavior and intention to use or not a product or service.

\section{b. Cutting Price (H2)}

Price cutting is one of the basic determinants of technology acceptance. Then the user will adopt a payment technology system if the system is easy to use and free of effort. Based on the explanation above, if the steps for using Go-Pay in cutting prices are very simple and do not take a long time then it shows a price cut for using the Go-Pay payment system is cheaper than the normal price. It is expected that Go-Jek companies can facilitate the adoption of Go-Pay payments to Go-Jek customers. Thus, price cuts must be adjusted specifically. Markets are dynamic, so adaptation and market adjustments are needed.

\subsection{Framework for Thinking}

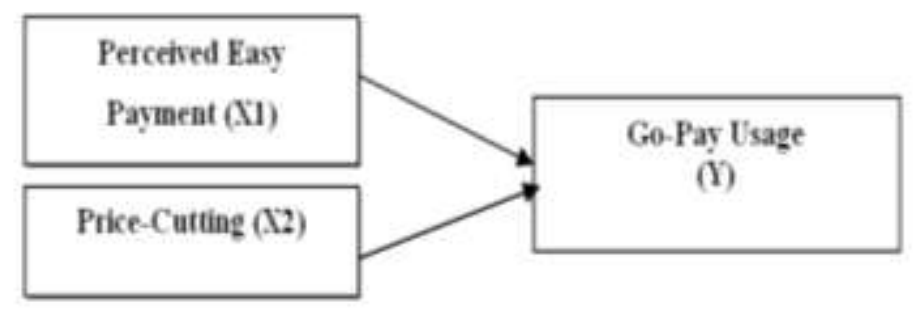

\section{Research Methods}

In carrying out this research, the author uses associative research, research that aims to find out the extent of influence or relationship between two or more variables and quantitative research is also research by obtaining data in the form of numbers or qualitative data that is assumed. The location of this research was carried out at Universitas Simalungun precisely at the Faculty of Economics, which is located at Jalan Sisingamangaraja Barat No.1 Pematangsiantar City.

Data sources used in this study are: Primary data is data obtained or collected directly in the field by researchers. Primary data is also called original data or new data. In this study data were obtained from PT. Go-jek. Data obtained by conducting questionnaires and secondary data is data obtained or collected by researchers who conduct research from existing sources. This data is usually obtained from the library or from previous research reports.

The variables used in this study are divided into two variables namely the dependent variable and the independent variable. The dependent variable in this study is the use of GoPay and the independent variable in this study is the Perception of easy payment and price cutting. The dependent variable is a stimulus variable or variable that affects other variables. The dependent variable examined in this study is the use of Go-pay (Y). The independent variable is the variable that gives a response / reaction if it is associated with the independent variable. Independent variables in this study are easy payment (X1) and price cutting (X2).

Data testing techniques in this study are descriptive analysis, quality test and classic assumption test. Hypothesis testing technique on this variable is multiple regression analysis 


\section{Discussion}

\subsection{Result}

\section{a. Results of Data Collection}

In the study of the influence of factors that influence consumers to pay with Go-pay, the object of research is Go-pay customers in Pematangsiantar. This researcher wants 50 questionnaires that Go-pay customers have answered. To reach 50 questionnaires that have been answered by the customer takes 2 weeks, no questionnaire is filled out incomplete so that all the questionnaires obtained can be processed.

\section{b. Description of Respondents}

Respondent characteristics used in this study were customers of 50 respondents, which included gender, age, majors, and semesters. These characteristics are expected to provide an overview of the state of the respondent in providing answers to the questionnaire. For more details, it can be presented as follows:

1) Characteristics based on gender

The following characteristics of customers by sex are shown in Table 1 .

Table 1. Gender

\begin{tabular}{|ll|r|r|r|r|}
\hline & Frequency & Percent & Valid Percent & Cumulative Percent \\
\hline Valid Man & 32 & 64,0 & 64,0 & 64,0 \\
& 18 & 36,0 & 36,0 & 100,0 \\
Woman & 50 & 100,0 & 100,0 & \\
Total & &
\end{tabular}

Source: SPSS Processing Results Version 23, 2019

From Table 1 states that customers who are willing to fill out the questionnaire are men with a percentage of $64 \%$ and women at $36 \%$. Based on these data, it can be concluded that respondents who are willing to fill out the questionnaire are dominated by men. This shows that the questionnaire answers from customers will greatly affect the results of research that is more likely to be feminine

2) Characteristics based on the Age

Table 2. Age

\begin{tabular}{|ll|r|r|r|r|}
\hline & & Frequency & Percent & Valid Percent & Cumulative Percent \\
\hline Valid & $18-19$ years old & 4 & 8,0 & 8,0 & 8,0 \\
& $20-21$ years old & 8 & 16,0 & 16,0 & 24,0 \\
& >22 years old & 38 & 76,0 & 76,0 & 100,0 \\
Total & 50 & 100,0 & 100,0 & \\
\hline
\end{tabular}

Source: SPSS Processing Results Version 23, 2019

In table 2 it can be seen that the majority of GO-PAY customers who are respondents are $>22$, as many as 38 people or $76 \%$ of the total respondents

3) Characteristics Based on Majors

Table 3. Majors

\begin{tabular}{|l|r|r|r|r|}
\hline & Frequency & Percent & Valid Percent & Cumulative Percent \\
\hline Valid Management & 50 & 100,0 & 100,0 & 100,0 \\
\hline
\end{tabular}

Source: SPSS Processing Results Version 23, 2019 
From table 3 states that the customers who filled out the questionnaire were Management with a percentage of $100 \%$. Based on these data, it can be concluded that the respondents who shared the questionnaire were dominated by Management.

4) Characteristics based on Semester

Table 4. Semester

\begin{tabular}{|ll|r|r|r|r|}
\hline & Frequency & Percent & Valid Percent & Cumulative Percent \\
\hline Valid & Semester V - & 4 & 8,0 & 8,0 & 8,0 \\
VIII & 46 & 92,0 & 92,0 & 100,0 \\
Semester I - IV & 50 & 100,0 & 100,0 & \\
Total & &
\end{tabular}

Source: SPSS Processing Results Version 23, 2019

c. Test the validity and Reliability Test

1) Validity test

Table 5. Validity Test (X1) Easy Payment Item-Total Statistics

\begin{tabular}{|l|r|r|r|r|r|}
\hline & $\begin{array}{l}\text { Scale Mean } \\
\text { if Item } \\
\text { Deleted }\end{array}$ & $\begin{array}{l}\text { Scale } \\
\text { Variance if } \\
\text { Item Deleted }\end{array}$ & $\begin{array}{l}\text { Corrected Item- } \begin{array}{l}\text { Total } \\
\text { Correlation }\end{array} \\
\begin{array}{l}\text { Squared } \\
\text { Multiple } \\
\text { Correlation }\end{array}\end{array}$ & $\begin{array}{l}\text { Cronbach's } \\
\text { Alpha if Item } \\
\text { Deleted }\end{array}$ \\
\hline Easy payment & 18,20 & 1,918 &, 328 &, 112 &, 656 \\
Easy payment & 18,60 & 1,265 &, 550 &, 528 &, 531 \\
Easy payment & 18,58 & 1,432 &, 382 &, 623 &, 622 \\
Easy payment & 18,50 & 1,276 &, 585 &, 545 &, 514 \\
Easy payment & 18,76 & 1,533 &, 293 &, 570 &, 665 \\
\hline
\end{tabular}

Source: SPSS Processing Results Version 23, 2019

From table 5 on the SPSS output results, the validity value is found in the Corrected Item-Total Correlation column, which means the correlation value between the score of each item with the total score on the respondent's answer tabulation. The validity test results of 5 (five) questions on the variable Price can be declared valid (valid) ) because all coefficients are greater than 0.05 .

Table 6. Validity Test (X2) Price-Cutting Item-Total Statistics

\begin{tabular}{|l|r|r|r|l|l|}
\hline & $\begin{array}{l}\text { Scale Mean } \\
\text { if Item } \\
\text { Deleted }\end{array}$ & $\begin{array}{l}\text { Scale } \\
\text { Variance if } \\
\text { Item Deleted }\end{array}$ & $\begin{array}{l}\text { Corrected } \\
\text { Item-Total } \\
\text { Correlation }\end{array}$ & $\begin{array}{l}\text { Squared } \\
\text { Multiple } \\
\text { Correlation }\end{array}$ & $\begin{array}{l}\text { Cronbach's } \\
\text { Alpha if Item } \\
\text { Deleted }\end{array}$ \\
\hline Price-Cutting & 17,76 & 1,778 &, 272 &, 077 &, 602 \\
Price-Cutting & 18,32 & 1,242 &, 429 &, 647 &, 507 \\
Price-Cutting & 18,22 & 1,277 &, 375 &, 744 &, 540 \\
Price-Cutting & 18,18 & 1,171 &, 492 &, 694 &, 467 \\
Price-Cutting & 18,40 & 1,429 &, 275 &, 710 &, 594 \\
\hline
\end{tabular}

Source: SPSS Processing Results Version 23, 2019

From table 6 on the SPSS output results, the validity value is found in the Corrected Item-Total Correlation column, which means the correlation value between the score of each item with the total score on the respondent's answer tabulation. The validity test results of 5 
(five) questions on the variable Price can be declared valid (valid) ) because all coefficients are greater than 0.05 .

Table 7. Validity Test (Y) for GO-PAY Usage

Item-Total Statistics

\begin{tabular}{|l|l|l|l|l|l|}
\hline & $\begin{array}{l}\text { Scale Mean } \\
\text { if Item } \\
\text { Deleted }\end{array}$ & $\begin{array}{l}\text { Scale } \\
\text { Variance if } \\
\text { Item Deleted }\end{array}$ & $\begin{array}{l}\text { Corrected } \\
\text { Item-Total } \\
\text { Correlation }\end{array}$ & $\begin{array}{l}\text { Squared } \\
\text { Multiple } \\
\text { Correlation }\end{array}$ & $\begin{array}{l}\text { Cronbach's } \\
\text { Alpha if Item } \\
\text { Deleted }\end{array}$ \\
\hline GO-PAY Usage & 18,12 & 1,781 &, 328 &, 114 &, 609 \\
GO-PAY Usage & 18,56 & 1,190 &, 498 &, 483 &, 491 \\
GO-PAY Usage & 18,50 & 1,357 &, 334 &, 624 &, 589 \\
GO-PAY Usage & 18,42 & 1,187 &, 553 &, 544 &, 460 \\
GO-PAY Usage & 18,72 & 1,471 &, 244 &, 587 &, 634 \\
\hline
\end{tabular}

Source: SPSS Processing Results Version 23, 2019

From table 7 on the SPSS output results the validity value is found in the Corrected Item-Total Correlation column, which means the correlation value between the score of each item with the total score in the tabulation of the respondent's answer. valid) because all the coefficients are greater than 0.05 .

2) Reliability Test

Reliability is the degree of accuracy, accuracy or accuracy shown by the measurement instrument. Questionnaire items are said to be reliable or reliable if someone's answer to the questionnaire is consistent. In this study to determine whether or not a reliable questionnaire using Cronbach alpha. Questionnaire is said to be reliable if alpha cronbach> 0.60 and not reliable if it is equal to or below 0.60 . The reliability of the questionnaire questions that the authors have asked the respondents in this study will be seen in the Reliability Statistics table presented in the table below:

Table 8. Reliability Test (X1) Easy Payment Reliability Statistics \begin{tabular}{|l|l|}
\hline Cronbach's Alpha & $\mathrm{N}$ of Items \\
\hline
\end{tabular} .657

From table 8 above, the results of SPSS output are known to be Cronbach's Alpha value -of $0,657>0.60$ so that it can be concluded that the questions that have been presented to respondents consisting of 5 items on the Easy Payment variable are reliable or said to be reliable.

Table 9. Discounted Reliability Test (X2)

Reliability Statistics

\begin{tabular}{|r|r|}
\hline Cronbach's Alpha & N of Items \\
\hline .603 & 5 \\
\hline
\end{tabular}

From table 9 above, the results of SPSS output are known to be Cronbach's Alpha value of $0.603>0.60$ so that it can be concluded that the question that has been presented to respondents consisting of 5 items on the price variable is reliable or said to be reliable. 
Table 10. Reliability Tests (Y) for GO-PAY Usage

Reliability Statistics

\begin{tabular}{|l|l|} 
Cronbach's Alpha & $\mathrm{N}$ of Items \\
\hline
\end{tabular}

.619

From table 10 above, the results of SPSS output are known to be Cronbach's Alpha value of $0.619>0.60$ so that it can be concluded that the questions that have been presented to respondents consisting of 5 statements on price variables are reliable or said to be reliable.

\section{d. Classical Assumption Test}

1) Multicollinearity Test

Multicollinearity test aims to test whether the regression model found a correlation between independent variables. This test is done by looking at the value of tolerance and variance inflation factor (VIF) from the results of the analysis using SPSS. If the tolerance value $>0.10$ or VIF $<10$, it can be concluded that multicollinearity does not occur. Multicollinearity Test from the results of the questionnaire that has been distributed to respondents can be seen in the following table:

Table 11. Multicollinearity Test

Coefficients $^{\mathrm{a}}$

\begin{tabular}{|c|c|c|c|c|c|c|c|c|}
\hline \multirow{2}{*}{\multicolumn{2}{|c|}{ Model }} & \multicolumn{2}{|c|}{$\begin{array}{l}\text { Unstandardized } \\
\text { Coefficients }\end{array}$} & \multirow{2}{*}{$\begin{array}{l}\text { Standardized } \\
\text { Coefficients } \\
\text { Beta } \\
\end{array}$} & \multirow[t]{2}{*}{$\mathrm{t}$} & \multirow[t]{2}{*}{ Sig. } & \multicolumn{2}{|c|}{$\begin{array}{l}\text { Collinearity } \\
\text { Statistics }\end{array}$} \\
\hline & & $\mathrm{B}$ & Std. Error & & & & Tolerance & VIF \\
\hline \multirow{5}{*}{1} & (Constant) & .137 & .554 & & .247 & .806 & & \\
\hline & Total & & & & & & & \\
\hline & Kemudahan & .840 & .033 & .870 & 25.689 & .000 & .452 & 2.211 \\
\hline & $\begin{array}{l}\text { Pembayaran } \times 1 \\
\text { Total }\end{array}$ & & & & & & & \\
\hline & $\begin{array}{l}\text { Pemotongan } \\
\text { Harga X2 }\end{array}$ & .154 & .034 & .152 & 4.505 & .000 & .452 & 2.211 \\
\hline
\end{tabular}

a. Dependent Variable: total go-pay usage $\mathrm{Y}$

Source: SPSS Processing Results Version 23, 2019

Based on Table 11 above, it can be seen that the Variance Inflation Factor (VIF) number is smaller than 10, among others, the easy payment of 2,211<10 and price cuts of $2,211<10$ and the Tolerance value of easy payment knowledge of $0.452<0.10$ and price cuts of $0.452<0.10$ thus free of multicollinearity.

\section{2) Heteroscedasticity Test}

Heteroskedacity test aims to test whether in the regression model there is an inequality of variance from the residuals of one observation to another. A good regression model is one that does not occur heteroskedacity. 


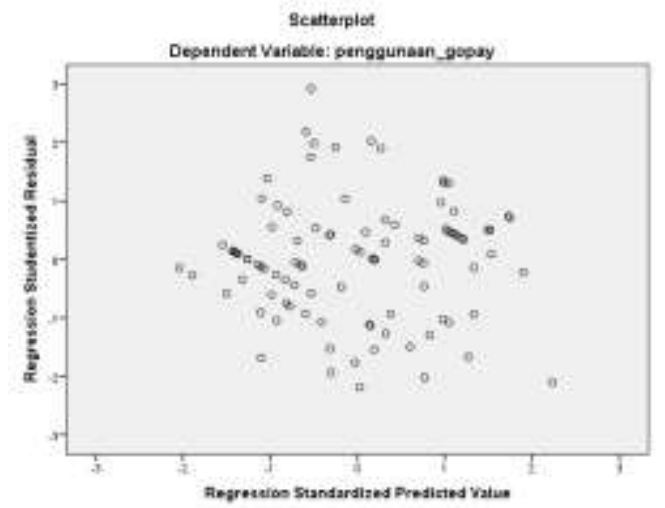

Source: SPSS Processing Results Version 23, 2019

Based on Figure 1 above, the scatterplot image shows that the resulting points spread randomly and do not form a particular pattern or line trend. The picture above also shows that the data distribution is around the zero point. From the results of this test indicate that this regression model is free from the problem of heteroscedasticity, in other words: the variables to be tested in this study are homoscedasticity.

\section{e. Analysis of Multiple Linear Regression}

Multiple linear regression aims to calculate the effect of two or more independent variables on one dependent variable and predict the dependent variable using two or more independent variables. The multiple regression analysis formula is as follows:

$\mathrm{Y}=\alpha+\mathrm{b}_{1} \mathrm{X}_{1}+\mathrm{b}_{2} \mathrm{X}_{2}+\mathrm{e}$

Table 12. Multiple Regression Analysis

Coefficients $^{\text {a }}$

\begin{tabular}{|c|c|c|c|c|c|}
\hline \multirow[t]{2}{*}{ Model } & \multicolumn{2}{|c|}{$\begin{array}{l}\text { Unstandardized } \\
\text { Coefficients }\end{array}$} & \multirow{2}{*}{$\begin{array}{l}\text { Standardized } \\
\text { Coefficients } \\
\text { Beta }\end{array}$} & \multirow[t]{2}{*}{$\mathrm{t}$} & \multirow[t]{2}{*}{ Sig. } \\
\hline & $\mathrm{B}$ & Std. Error & & & \\
\hline (Constant) & .137 & .554 & & .247 & 806 \\
\hline Total easy payment X1 & .840 & .033 & .870 & 25.689 & .000 \\
\hline $\begin{array}{l}\text { Total price-cutting } \\
\text { X2 }\end{array}$ & .154 & .034 & .152 & 4.505 & .000 \\
\hline
\end{tabular}

a. Dependent Variable: total go-pay usage $\mathrm{Y}$

Source: SPSS Processing Results Version 23, 2019

Based on table 12, the constant value of the regression coefficient can be form as:

$$
\mathrm{Y}=0.137+-0.840 \mathrm{X} 1-0.154 \mathrm{X} 2+\mathrm{e}
$$

From this equation can be explained as follows:

- A constant value of 0.137 means that the independent variable means that the independent variable means $\mathrm{X} 1$ and $\mathrm{X} 2$ are equal to 0 , so the $\mathrm{Y}$ value is 0.137 .

- The value of the regression coefficient for the easy payment variable (X1) is 0.840 positive direction, meaning that each improvement in the quality of payment convenience is 1 and other variables remain satisfying customer satisfaction will experience an increase of 0.840 .

- The value of the regression coefficient for cutting price variable (X2) is 0.154 positive direction, meaning that if there is an increase in the cutting price 1 point and other variables remain, then customer satisfaction will experience an increase of 0.154 


\section{f. Hypothesis Testing}

1) T test (partial)

- T test is used to determine whether there is a significant influence between independent variables partially on the dependent variable. With the basic decision making as follows:

- Decision making based on probability values:

- If the sig value<error level $(\alpha=0.60)$, then $\mathrm{H}_{\mathrm{a}}$ is accepted and $\mathrm{H}_{0}$ is rejected, which means that there is an independent variable with a dependent variable in par.

- If the value of $\mathrm{sig}>$ error level $(\alpha=0.60)$, then $\mathrm{H}_{0}$ is accepted and $\mathrm{H}_{\mathrm{a}}$ is rejected which means that the woman can not influence the independent variable with the partial dependent variable.

Table 13. Test $t$

Coefficients ${ }^{\mathrm{a}}$

\begin{tabular}{|c|c|c|c|c|c|}
\hline \multirow{2}{*}{\multicolumn{2}{|c|}{ Model }} & \multicolumn{2}{|c|}{$\begin{array}{l}\text { Unstandardized } \\
\text { Coefficients }\end{array}$} & \multirow{2}{*}{$\begin{array}{l}\text { Standardized } \\
\text { Coefficients } \\
\text { Beta }\end{array}$} & \multirow[t]{2}{*}{ Sig. } \\
\hline & & B & Std. Error & & \\
\hline \multirow{3}{*}{1} & (Constant) & .137 & .554 & & .806 \\
\hline & Total easy payment X1 & .840 & .034 & .870 & .000 \\
\hline & Total price-cutting X2 & .154 & .034 & .152 & .000 \\
\hline
\end{tabular}

a. Dependent Variable: total go-pay usage $\mathrm{Y}$

Source: SPSS Processing Results Version 23, 2019

Based on table 13 above can be explained:

- Significant Value of easy payment, $0,000<0.60$, then $\mathrm{H}_{\mathrm{a}}$ received by $\mathrm{H}_{0}$ in reject so that easy payment has a significant influence on the use of Go-Pay.

- Significant value cuts, $0,000<0.60$ so $\mathrm{H}_{\mathrm{a}}$ in accepts and $\mathrm{H}_{0}$ is rejected so that price cuts have a significant effect on the use of Go-Pay.

2) F Test (Simultaneous)

$F$ test is performed to determine the effect of the independent variables on the dependent variable simultaneously (together).

- If the value of sig <error level $(\alpha=0.60)$, then $\mathrm{H}_{\mathrm{a}}$ is accepted and $\mathrm{H}_{0}$ is rejected which means that there can be a simultaneous effect between the independent variable and the dependent variable.

- If the value of sig > error rate $(\alpha=0.60)$, then $\mathrm{H}_{0}$ is accepted and $\mathrm{H}_{\mathrm{a}}$ is rejected which means that the woman can have a simultaneous effect between the independent variable and the dependent variable.

Table 14. Test F (Simultaneous)

ANOVA $^{\mathrm{a}}$

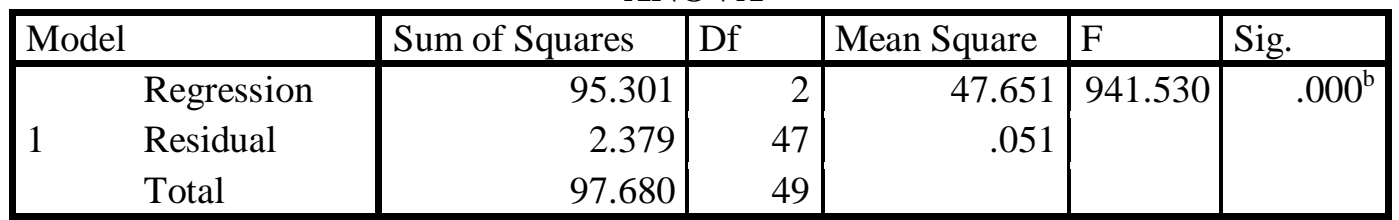

a. Dependent Variable: total go-pay usage Y

b. Predictors: (Constant), total easy payment X1, total price-cutting X2

Source: SPSS Processing Results Version 23, 2019 
From table 14 it can be explained that with a sig value of $0,000<0.60$, then $\mathrm{H}_{\mathrm{a}}$ is accepted and $\mathrm{H}_{0}$ is rejected so it can be concluded that there is a significant influence between the easy payment (X1) and price-cutting (X2) simultaneously there is the use of Go-Pay (Y ).

\section{3) Coefficient of Determination}

Table 15. Determination Coefficients

Model Summary

\begin{tabular}{|c|c|c|c|c|}
\hline Model & $\mathrm{R}$ & R Square & $\begin{array}{l}\text { Adjusted R } \\
\text { Square }\end{array}$ & $\begin{array}{l}\text { Std. Error of the } \\
\text { Estimate }\end{array}$ \\
\hline 1 & $.988^{\mathrm{a}}$ & .976 & .975 & .225 \\
\hline
\end{tabular}

a. Predictors: (Constant), total easy payment X1, total price-cutting X2

Source: SPSS Processing Results Version 23, 2019

In table 15 above shows that the influence of the variable easy payment and price cuts there is the use of G0-Pay is $97.6 \%$ while the remaining $2.4 \%$ has been investigated by researchers.

\subsection{Discussion}

This study aims to determine the effect of service quality such as easy payment and price cuts on the use of Go-Pay on Gojek transportation services, especially on Go-Pay. So in this study obtained by distributing questionnaires to esponden and collect again. Researchers tested data analysis using SPSS version 23.

\section{a. Effect of Easy Payment on Go-Pay Usage}

The results showed that there was an influence of easy payment on the use of Go-pay. This is evident that the easy payment variable has a positive and significant effect. The assessment of Universitas Simalungun (USI) Faculty of Economics Pematangsiantar as a customer of the easy payment affects the Go-pay recommended by Gojek customers. Consumers pay too much attention to the type / condition of the vehicle used by the Gojek driver, the attributes of the vehicle given, the appearance and neatness of the driver and the appearance of the Gojek application itself. Thus means the easey payment has an influence on the satisfaction felt by consumers.

\section{b. Effect of Price Monitoring on Go-Pay Usage}

The results showed that there was an effect of price cutting on the use of Go-pay. This is evident that the variable price cut has a positive and significant effect. The price cuts provided by Gojek affect the satisfaction felt by customers. This provides evidence that price cuts can make it easier for customers to use a variety of products in Gojek such as Go-Ride, Go-Car, GoFood, Go-Pulses, Go-Send, Go-Point, Go-Bills, Go-Box, Go-Mart, Go-Tix, and Go Med to get cheaper prices than normal prices. Thus it means that price cuts have an influence on the satisfaction felt by consumers.

\section{c. Effect of Ease of Financing and Cutting Price on Go-Pay Usage}

By using the F Test it can be explained that there is a significant effect between the easy payment and simultaneous price cuts on the use of G0-Pay. The R2 determinant test results in this study amounted to 0.976 which means that the magnitude of the effect of variable easy payment and price cutting on the use of Go-pay while the remaining $2.4 \%$ was not examined in this researcher. 


\section{Conclusion}

From the results of the multiple linear regression analysis that has been done, the conclusions that can be drawn in this study are:

- The easy payment variable has a positive and significant effect on the use of Go-Pay services for customers.

- Price cutting variable has a positive and significant effect on Go-Pay usage services for customers.

- The level of income simultaneously affects employee performance. This is evidenced by the coefficient of determination test (R2), which is the R-Square value of $0.976(97.6 \%)$. This means that $97.6 \%$ of the dependent variable, namely Price Cutting (Y) can be explained by the independent variable, namely Easy Payment $(\mathrm{X})$. While the remaining $2.4 \%$ is influenced by other variables not examined in this study.

\section{References}

Ahuja, M., Gupta, B., Raman, P., 2003. An empirical investigation of online consumer purchasing behavior. Commun. ACM 46, 145. https://doi.org/10.1145/953460.953494

Arikunto, Suharsimi. 2010. Prosedur Penelitian Suatu Pendekatan Praktik. Jakarta : Rineka Cipta.

Aritonang dan Arisman, 2017. Pengaruh persepsi kemudahan dan persepsi manfaat terhadap minat menggunakan E-money (Studi Kasus pada pengguna Go-Pay). Jurnal.http://eprints.mdp.ac.id/2292/1/JURNAL- 2014210066.pdf

Devaraj, S., Fan, M., Kohli, R., 2003. E-loyalty: elusive ideal or competitive edge? Commun. ACM 46, 184. https://doi.org/10.1145/903893.903936

Ghozali, Imam. 2011. Aplikasi Analisis dengan Program SPSS. Semarang: Badan Penerbit Universitas Diponegoro.

Philip Kotler \& Keller, K.L. 2008. Manajemen Pemasaran. Edisi 12. Jilid 1. Alih Bahasa Benyamin Molan. Penerbit PT Indeks: Jakarta.

Priyono, 2017. Analisis pengaruh trust dan risk dalam penerimaan teknologi dompet elektronikGo-Pay.

https://www.researchgate.net/publication/31712983_analisis_pengaruh_trust_dan_risk_ dalam_penerimaan_teknoligi_dompet_elektronik_Go-pay.

Sugiyono.(2017). Metode Penelitian Kuantitatif, Kualitatif, dan R\&D. Bandung: Alfabeta

Swastha, Basu. 2000. Azas-azas Marketing. Liberty. Yogyakarta.

Thixmandan Tileng,2016. Analisis pengaruh usability, reputasi, dan keamanan terhadap kepercayaan masyarakat dalam bertransaksi menggunakan E-Money di Indonesia.

Jurnal. Source : https://dspace.uc.ac.id/handle/123456789/1646

www.gojekindonesia.com

https://www.maxmanroe.com/vid/bisnis/pengertian-konsumen.html

https://utamarizky.blogspot.com/2018/11/harga-definisi-peranan-tahapan-dan.html 